\title{
Hypoxia and hypoglycaemia in Ewing's sarcoma and osteosarcoma: regulation and phenotypic effects of Hypoxia-Inducible Factor
}

\author{
Helen J Knowles ${ }^{*}$, Karl-Ludwig Schaefer ${ }^{2}$, Uta Dirksen ${ }^{3}$, Nicholas A Athanasou ${ }^{4}$
}

\begin{abstract}
Background: Hypoxia regulates gene expression via the transcription factor HIF (Hypoxia-Inducible Factor). Little is known regarding HIF expression and function in primary bone sarcomas. We describe HIF expression and phenotypic effects of hypoxia, hypoglycaemia and HIF in Ewing's sarcoma and osteosarcoma.

Methods: HIF- $1 \alpha$ and HIF-2 $\alpha$ immunohistochemistry was performed on a Ewing's tumour tissue array. Ewing's sarcoma and osteosarcoma cell lines were assessed for HIF pathway induction by Western blot, luciferase assay and ELISA. Effects of hypoxia, hypoglycaemia and isoform-specific HIF siRNA were assessed on proliferation, apoptosis and migration.

Results: $17 / 56$ Ewing's tumours were HIF-1 $\alpha$-positive, 15 HIF-2 $\alpha$-positive and 10 positive for HIF-1 $\alpha$ and HIF-2 $\alpha$. Expression of HIF- $1 \alpha$ and cleaved caspase 3 localised to necrotic areas. Hypoxia induced HIF- $1 \alpha$ and HIF- $2 \alpha$ in Ewing's and osteosarcoma cell lines while hypoglycaemia specifically induced HIF-2 $\alpha$ in Ewing's. Downstream transcription was HIF-1 $\alpha$-dependent in Ewing's sarcoma, but regulated by both isoforms in osteosarcoma. In both cell types hypoglycaemia reduced cellular proliferation by $\geq 45 \%$, hypoxia increased apoptosis and HIF siRNA modulated hypoxic proliferation and migration.

Conclusions: Co-localisation of HIF-1 $1 \alpha$ and necrosis in Ewing's sarcoma suggests a role for hypoxia and/or hypoglycaemia in in vivo induction of HIF. In vitro data implicates hypoxia as the primary HIF stimulus in both Ewing's and osteosarcoma, driving effects on proliferation and apoptosis. These results provide a foundation from which to advance understanding of HIF function in the pathobiology of primary bone sarcomas.
\end{abstract}

\section{Background}

Hypoxia is a fundamental micro-environmental component of solid tumour tissue which is associated with resistance to therapy, poor survival and a malignant phenotype [1]. Hypoxia induces stabilisation of the Hypoxia-Inducible Factor transcription factors, HIF-1 and HIF-2, which direct responses central to survival and expansion of the malignant cell population.

HIF comprises a hypoxia-inducible alpha subunit and a constitutively expressed beta subunit. Regulation of the active transcription factor occurs via enzymatic control of the abundance and activity of HIF $\alpha$ subunits. Under normoxia $\mathrm{HIF} \alpha$ is post-translationally

\footnotetext{
* Correspondence: helen.knowles@ndorms.ox.ac.uk
'Botnar Research Centre, University of Oxford, Nuffield Orthopaedic Centre,

* Correspondence: helen.knowles@ndorms.ox.ac.uk
'Botnar Research Centre, University of Oxford, Nuffield Orthopaedic Centre, Oxford, OX3 7LD, UK
} Oxford, OX3 $71 \mathrm{D}$, UK

hydroxylated by the prolyl hydroxylase domain enzymes, targeting it for proteasomal degradation $[2,3]$. These enzymes are absolutely dependent on $\mathrm{O}_{2}$ and limitation of activity under hypoxia allows stabilisation of HIF . Binding of the active complex to the hypoxia-response element (HRE) of target genes results in activation of pathways regulating processes such as angiogenesis, apoptosis and metabolic adaptation [4].

HIF over-expression is an independent prognostic factor in many carcinomas [5], although limited data is available in primary bone sarcomas. Nuclear overexpression of HIF-1 $\alpha$ has been reported in approximately $60 \%$ of clinical osteosarcomas where it correlates with disease grade, stage, recurrence and survival [6-8]. In Ewing's sarcoma the presence of tumour cell-lined blood lakes correlates with clinical outcome. Cells surrounding these lakes also express HIF- $1 \alpha$ and the 
hypoxia marker pimonidazole [9]. Expression of both HIF- $1 \alpha$ and HIF- $2 \alpha$ has been reported in chondrosarcoma [10] and giant cell tumour of bone [11], HIF-1 $\alpha$ expression correlating with reduced disease-free survival in chondrosarcoma. Levels of serum VEGF, a HIF target gene, are significantly higher in Ewing's patients than healthy controls [12] and are an independent prognostic factor for survival [13]. In osteosarcoma VEGF levels were higher in the tumour and serum of patients who subsequently relapsed, tumour VEGF being predictive of pulmonary metastasis and poor prognosis [14,15]. In Ewing's sarcoma the presence of necrotic, non-perfused and presumably hypoxic tumour areas correlates with survival and frequency of metastatic spread [16-18].

This data implies that hypoxia and/or HIF contribute substantially to the pathobiology of primary bone sarcomas. Hypoxia induces expression of HIF- $1 \alpha$ and VEGF in the osteosarcoma cell lines Saos2, 143B, U2-OS and MG-63 [11,19-21], with MG-63 also expressing HIF-2 $\alpha$ $[11,22]$. The Ewing's sarcoma cell lines A673, SK-ES-1, SK-N-MC and TC-71 also demonstrate hypoxic induction of HIF- $1 \alpha$ and downstream genes [23-25]. Despite such evidence for hypoxic activation of the HIF transcriptional cascade in osteosarcoma and Ewing's sarcoma cells, little is known regarding the effect of either HIF- $1 \alpha$ or HIF- $2 \alpha$ on the hypoxic phenotype of these cells. We have therefore analysed characteristics of the induction of HIF- $1 \alpha$, HIF- $2 \alpha$ and HIF target genes in a panel of osteosarcoma and Ewing's sarcoma cell lines and investigated effects of isoform-specific HIF siRNA on the hypoxic phenotype of these cells.

\section{Methods \\ Reagents}

Tissue culture reagents were from Lonza (Wokingham, UK), except FBS (Invitrogen, Paisley, UK). Unless otherwise stated, reagents were from Sigma (Poole, UK). This study was approved by the Oxford Clinical Research Ethics Committee (C01.071).

\section{Immunohistochemistry}

A tissue array comprising 47 Ewing's sarcomas was constructed at the University of Dusseldorf. Additional sections were from the Nuffield Orthopaedic Centre. Formalin fixed sections were stained for HIF-1 $\alpha$ (BD Biosciences, Oxford, UK), HIF-2 $\alpha$ (EP190b, Abcam, Cambridge, UK), Glut-1 (Abcam) and cleaved caspase 3 (Cell Signalling Technology, Danvers, USA). Staining was visua-

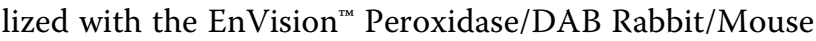
detection kit (Dako, Ely, UK). Image acquisition was performed using an Olympus BX40 microscope with 20x or $40 \times$ objective, Olympus DP70 camera and CellF. Tumours were considered positive for an antigen when $\geq 3$ positive cells/field of view were observed at $20 \times$ magnification.

\section{Cell culture}

Cell lines were obtained from the EuroBoNeT cell line biobank, comprising recently characterised bone tumour cell lines [26], and maintained in culture for $<30$ passages. All cell lines were maintained in RPMI (except TC-71; IMDM) with 10\% FBS, L-glutamine (2 mM), penicillin $(50 \mathrm{IU} / \mathrm{ml})$ and streptomycin sulphate $(50 \mu \mathrm{g} /$ $\mathrm{ml})$ in a humidified atmosphere at $37^{\circ} \mathrm{C}\left(5 \% \mathrm{CO}_{2}\right.$ in air). Hypoxic exposures were performed in $0.1 \% \mathrm{O}_{2}, 5 \% \mathrm{CO}_{2}$, balance $\mathrm{N}_{2}$ in a MiniGalaxy incubator (RS Biotech, Irvine, UK). Low glucose conditions were achieved using RPMI media without glucose, supplemented as for normal media, under normoxic conditions.

\section{Western blotting}

Cells were homogenized in lysis buffer (6.2 M urea, 10\% glycerol, 5 M DTT, 1\% SDS, protease inhibitors). Whole cell extract was separated by $8 \%$ SDS-PAGE and transferred to PVDF membrane. Primary antibodies were against HIF- $1 \alpha$, HIF-2 $\alpha$, Glut-1, Ki-67 (MIB-1, Dako) and $\beta$-tubulin. Immuno-reactivity was visualised with HRP-linked goat serum and chemiluminescence. Densitometric quantification of $\mathrm{Ki}-67$, normalised to $\beta$-tubulin, was performed on scanned blots using ImageJ.

\section{Luciferase assay}

Cells at $60 \%$ confluence were transfected with a PGKHRE-firefly luciferase reporter construct and the control pHRG-TK renilla luciferase plasmid (Promega, Southampton, UK) using Lipofectamine 2000 (Invitrogen). 24 $\mathrm{h}$ post-transfection cells were exposed to experimental conditions then lysed in Passive Lysis Buffer. Firefly and renilla luciferase were assayed using the Dual-Luciferase Reporter Assay System (Promega), with firefly luciferase values normalized to the renilla transfection control.

\section{ELISA}

Secretion of VEGF and TGF $\alpha$ was measured using the Human VEGF DuoSet and Quantikine Human TGF $\alpha$ Immunoassay (R\&D Systems, Abingdon, UK) respectively.

\section{Cell number, proliferation and apoptosis}

Cellular apoptosis was assessed using the Apo-One Homogeneous Caspase-3/7 Assay (Promega), with apoptosis levels normalised to total cell number (CellTiter 96 Aqueous One Solution Cell Proliferation Assay, Promega). For quantification of mitotic index cells were fixed in formalin, stained for $H \& E$ and the number of mitotic figures was expressed as a percentage of total cell number in 4 random fields of view.

\section{siRNA transfection}

Small interfering RNA (siRNA) sequences against HIF$1 \alpha(\mathrm{H} 1), \mathrm{HIF}-2 \alpha(\mathrm{H} 2)$ and HIF- $1 \alpha$ scrambled control 
(scr) were as described [27] and obtained pre-annealed from Eurogentec. Cells at $40 \%$ confluence were transfected with $50 \mathrm{nM}$ siRNA duplex using Lipofectamine 2000. Duplexes were removed after $24 \mathrm{~h}$ and cells treated as required.

\section{Scratch migration assay}

A scratch was made through cells at $90 \%$ confluence using a $20 \mathrm{ul}$ pipette tip. Specific points of the scratch were photographed before and after exposure to experimental conditions. Wound width was measured in CellF and migration expressed as fraction wound closure.

\section{Statistical significance}

Results are expressed as mean \pm SD of at least three independent experiments. Statistical analysis comprised one-way ANOVA using Bonferroni's multiple comparison as a post-hoc test, with results considered significant at $\mathrm{p}<0.05$.

\section{Results}

\section{HIF-1 $\alpha$ and HIF-2 $\alpha$ are expressed in Ewing's sarcoma}

As HIF- $1 \alpha$ has already been described to correlate with clinical and survival parameters in osteosarcoma, immunohistochemistry focussed on Ewing's sarcoma. Of 56 Ewing's tumours assessed for expression of HIF; $30 \%$ expressed only HIF- $1 \alpha, 27 \%$ only HIF- $2 \alpha, 18 \%$ both HIF- $1 \alpha$ and HIF- $2 \alpha$ and $25 \%$ neither HIF isoform. HIF$1 \alpha$ was predominantly localised in the nucleus of Ewing's tumour cells, whereas HIF- $2 \alpha$ expression was mainly cytoplasmic (Figure 1A, B). In tumours expressing both HIF- $1 \alpha$ and HIF- $2 \alpha$ there was no evidence of co-localisation and no correlation in intensity of staining. In 17 of the $27 \mathrm{HIF}-1 \alpha$-positive cases expression of HIF-1 $\alpha$ was associated with regions of necrosis, areas of tissue also immunoreactive for the apoptosis marker cleaved caspase 3 (Figure 1C, D). No such relationship was evident for HIF- $2 \alpha$. With the clinical data available, no correlation was observed between HIF expression and clinical parameters including tumour volume, metastasis and survival.

\section{Differential HIF response of ES and OS cells to hypoxia and low glucose}

HIF-1 $\alpha$ protein was stabilised in response to hypoxia in all Ewing's (ES) and osteosarcoma (OS) cell lines tested. Hypoxia induced the HIF- $2 \alpha$ isoform in all OS and in 4/5 ES cell lines (Figure 2A). Low glucose conditions were also assessed as an additional micro-environmental characteristic of regions of necrosis. Low glucose produced no HIF response in any OS cell line, while ES cells displayed strong induction of HIF- $2 \alpha$ protein and a moderate increase in HIF-1 $\alpha$ in SK-ES-1 and SK-N-MC (Figure 2B). This pattern of HIF induction was reflected in transcriptional events downstream of HIF. Both ES and OS cells strongly transactivated the HRE-promoter element in response to hypoxia and induced expression of the HIF target genes, Glut-1 and VEGF (Figure 2A, C, D). ES cells induced expression of both Glut-1 and VEGF in response to low glucose, although the magnitude of induction was less than for hypoxia and no transcriptional activation was evident in the HRE promoterluciferase assay (Figure 2B-D). OS cells showed no HIF transcriptional response to low glucose conditions.

\section{Distinct transcriptional effects of HIF- $1 \alpha$ and HIF- $2 \alpha$ in ES and OS cells}

Isoform-specific HIF siRNA was used to distinguish the relative contribution of HIF- $1 \alpha$ and HIF- $2 \alpha$ to the HIF transcriptional response. In ES cell lines, HIF-2 $\alpha$ siRNA had no effect on Glut-1 expression (Figure 3A), VEGF secretion (Figure 3B) or HRE-luciferase activity (Figure 3C). HIF-1 $\alpha$ siRNA significantly inhibited hypoxic induction of Glut-1, VEGF and HRE transactivation (Figure 3A-C). Normoxic levels of Glut-1 and VEGF were also reduced by HIF- $1 \alpha$ siRNA, even in the absence of immuno-detectable HIF (Figure 3A, B). However, hypoxia and low glucose both induced secretion of HIF-2-specific TGF $\alpha[28,29]$ in ES cell lines which express the HIF-2 isoform (Figure 3D). In contrast, HIF transactivation in OS cell lines was regulated by a combination of both transcription factors. Suppressed hypoxic induction of Glut-1 (Figure 3A), VEGF (Figure $3 \mathrm{~B}$ ) and HRE-luciferase activity (Figure 3C) was evident with siRNA targeting either HIF- $1 \alpha$ or HIF- $2 \alpha$, combined 'HIF- $1 \alpha$ plus HIF- $2 \alpha$ ' siRNA generally exhibiting an additive effect.

\section{Phenotypic effects of hypoxia and low glucose in ES and OS cell lines}

Phenotypic effects of $72 \mathrm{~h}$ exposure to hypoxia or low glucose conditions were assessed in a reduced panel of 3 ES and 3 OS cell lines. Hypoxia had no effect on total cell number in any cell line except $143 \mathrm{~B}$, whereas low glucose consistently reduced cell number by $>45 \%$ (Figure 4A). Caspase 3/7 activation was assessed as a marker of cellular apoptosis. Hypoxia increased apoptosis in both cell panels, having a 2 to 3 -fold greater effect in OS cell lines. Glucose deprivation only had a significant effect on apoptosis in SK-ES-1 (Figure 4B). Proliferation was measured in OS cells by mitotic index and in ES cells by immuno-detection of Ki-67. The percentage of mitoses generally did not change during exposure to hypoxia, but was reduced by low glucose conditions (Figure 4C). Similarly, Ki-67 expression was inhibited by low glucose conditions but maintained on exposure to hypoxia (Figure 4D). 


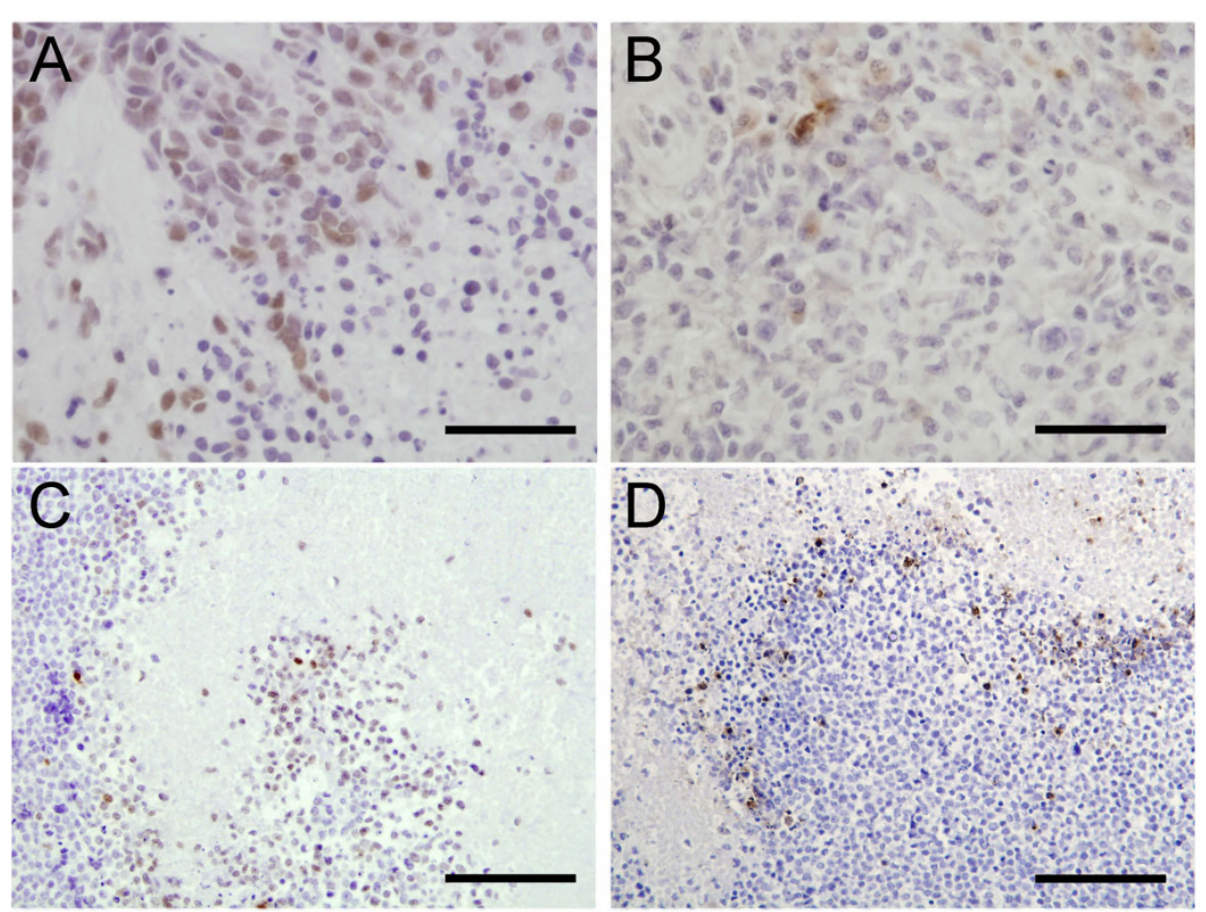

Figure 1 Expression of HIF in Ewing's sarcoma. (a) HIF- $1 \alpha$ and (b) HIF-2 $\alpha$ expression in Ewing's tumour cells; scale bar $=50 \mu \mathrm{m}$. Expression of HIF-1 $\alpha$ (c) co-localises with that for cleaved caspase 3 (d); scale bar $=100 \mu \mathrm{m}$.

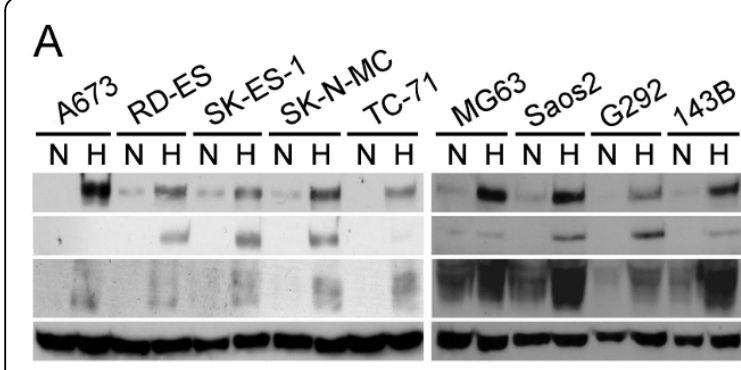

B
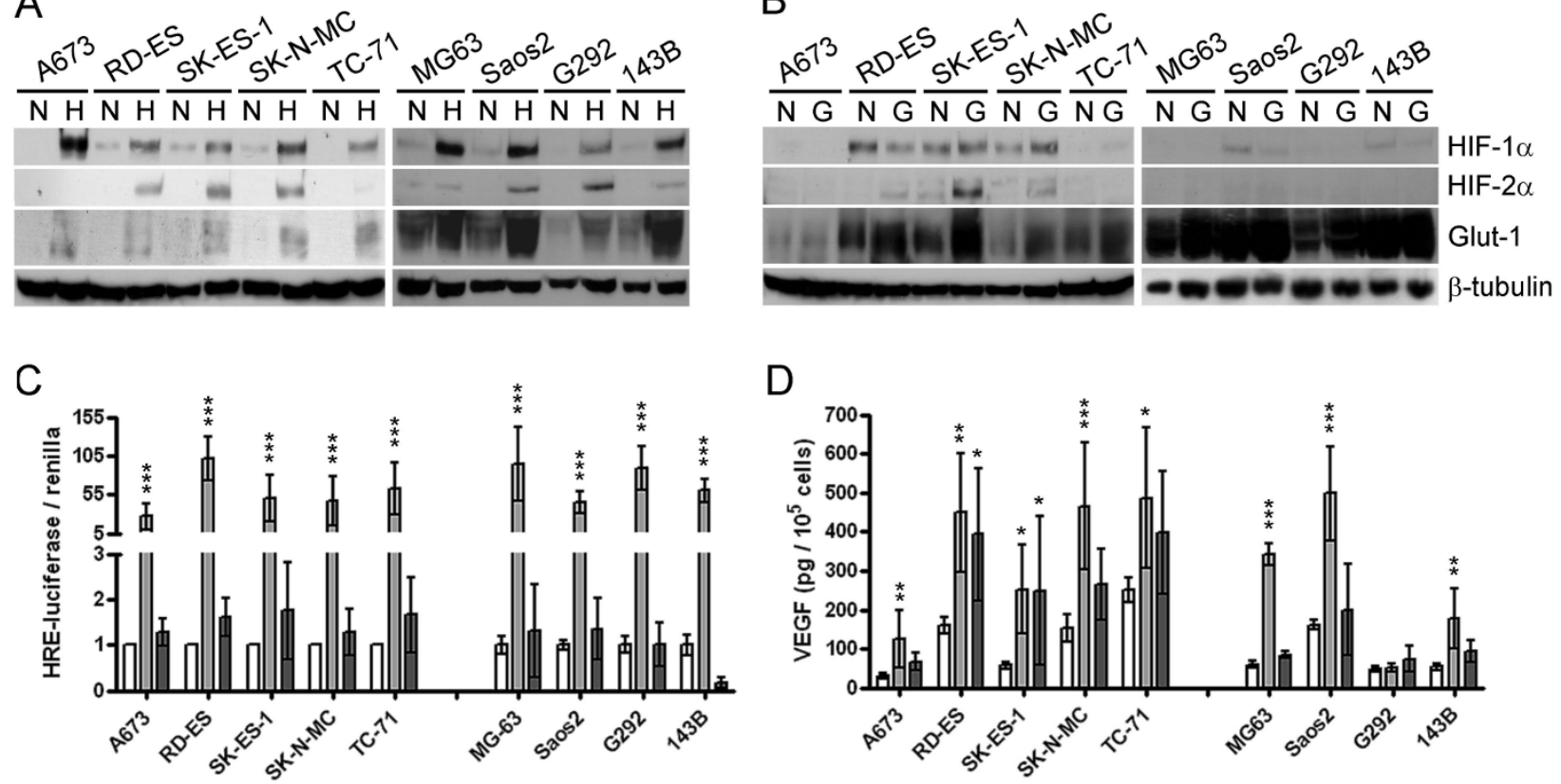

D

Figure 2 HIF induction in ES and OS cell lines. Western blots showing induction of HIF-1 $\alpha$ (120 kDa), HIF-2 $\alpha$ (120 kDa) and Glut-1 (50 kDa) in a panel of ES (A673, RD-ES, SK-ES-1, SK-N-MC, TC-71) and OS (MG-63, Saos2, G292, 143B) cell lines in response to $24 \mathrm{~h}$ (a) hypoxia $\left(\mathrm{H}_{;} ; 0.1 \% \mathrm{O}_{2}\right)$ or (b) low glucose (G; over-exposed in comparison to hypoxia blots) compared with the untreated/normoxic (N) control. (c) Activation of the HRE-luciferase reporter construct and (d) secretion of VEGF in response to hypoxia (light grey bars) or low glucose (dark grey bars). ${ }^{*}, \mathrm{p}<0.05$; **, $\mathrm{p}<0.01 ;{ }^{* * *}, \mathrm{p}<0.001$. 


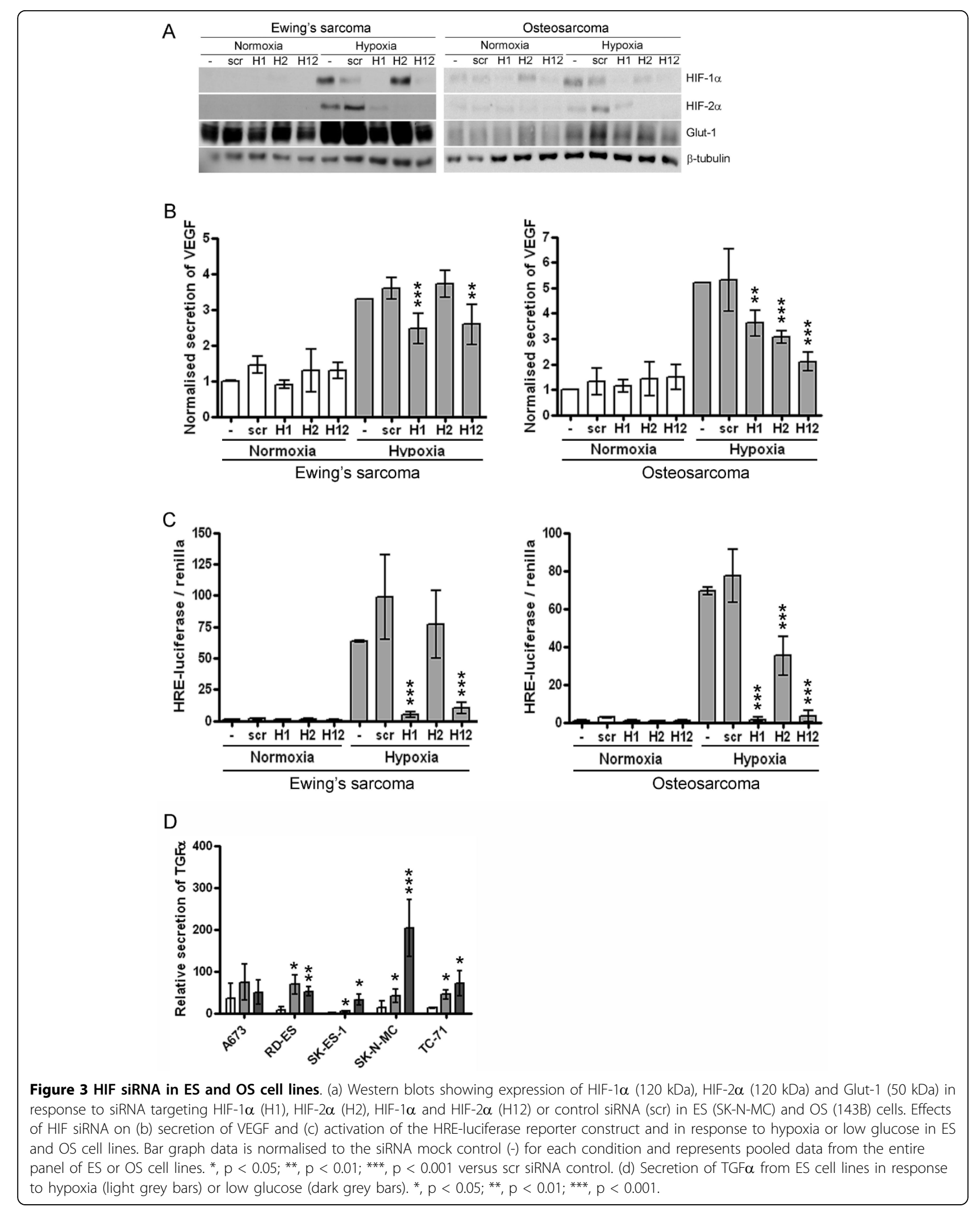




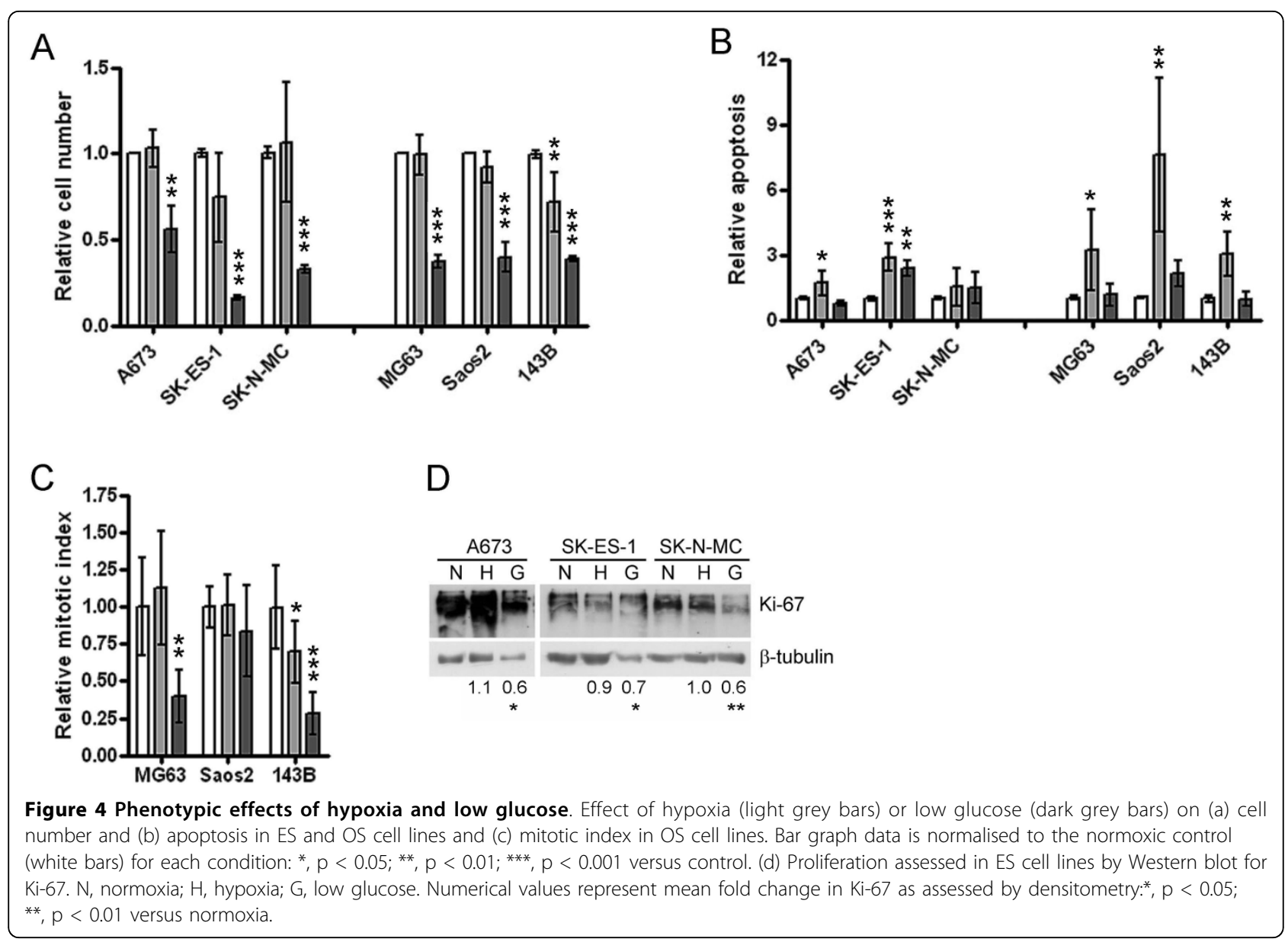

\section{Effect of HIF siRNA on the hypoxic phenotype}

Since no differences were observed between ES and OS cell lines regarding phenotypic effects of glucose deprivation, and as OS cells have no HIF transcriptional response to this stimulus, effects of HIF siRNA were only investigated under hypoxia. No effect was observed on cell number or apoptosis under hypoxia with the exception of a minor increase in OS cell number with HIF- $2 \alpha$ siRNA, the magnitude of which questions its biological significance (Figure 5A, B). However, in ES cells HIF-1 $\alpha$ siRNA consistently increased cell proliferation under hypoxia as assessed by Western blotting for Ki-67 (Figure 5C). Conversely, siRNA targeting either HIF- $1 \alpha$ or HIF- $2 \alpha$ resulted in reduced hypoxic proliferation in $2 / 3$ OS cell lines, although siRNA targeting either HIF- $1 \alpha$ or HIF- $2 \alpha$ in 143B cells produced the opposite effect (Figure 5D).

\section{Effect of hypoxia and HIF on cell migration}

ES and OS cell lines responded in an opposing manner with respect to cell migration during exposure to $18 \mathrm{~h}$ hypoxia. ES cell migration was inhibited by $65-80 \%$ under hypoxia, whereas OS cells showed a trend to increased hypoxic migration (Figure 6A). Despite contrasting responses to the initial stimulus, both ES and OS cells demonstrated similar responses to HIF siRNA, with targeted inhibition of HIF- $2 \alpha$ resulting in increased cell migration under hypoxia (Figure 6B).

\section{Discussion}

These results provide the first detailed description of HIF induction by micro-environmental conditions relevant to primary bone tumours in Ewing's sarcoma and osteosarcoma. We have described phenotypic effects of these conditions, outlining the HIF dependence of these phenotypes and differences between the two tumour types regarding these responses.

Work in many cell types describes HIF- $1 \alpha$ as constitutively hypoxia-regulated and HIF- $2 \alpha$ as more cell type specific, its transcriptional activation being influenced by micro-environmental conditions other than hypoxia [30,31]. Despite both isoforms sharing an identical core binding motif, the majority of HIF-regulated hypoxiainducible genes are induced by HIF- $1 \alpha$ alone or by a combination of both HIF- $1 \alpha$ and HIF- $2 \alpha$ [27,31-33]. Our results in ES cells reflect this, with HIF-regulated 


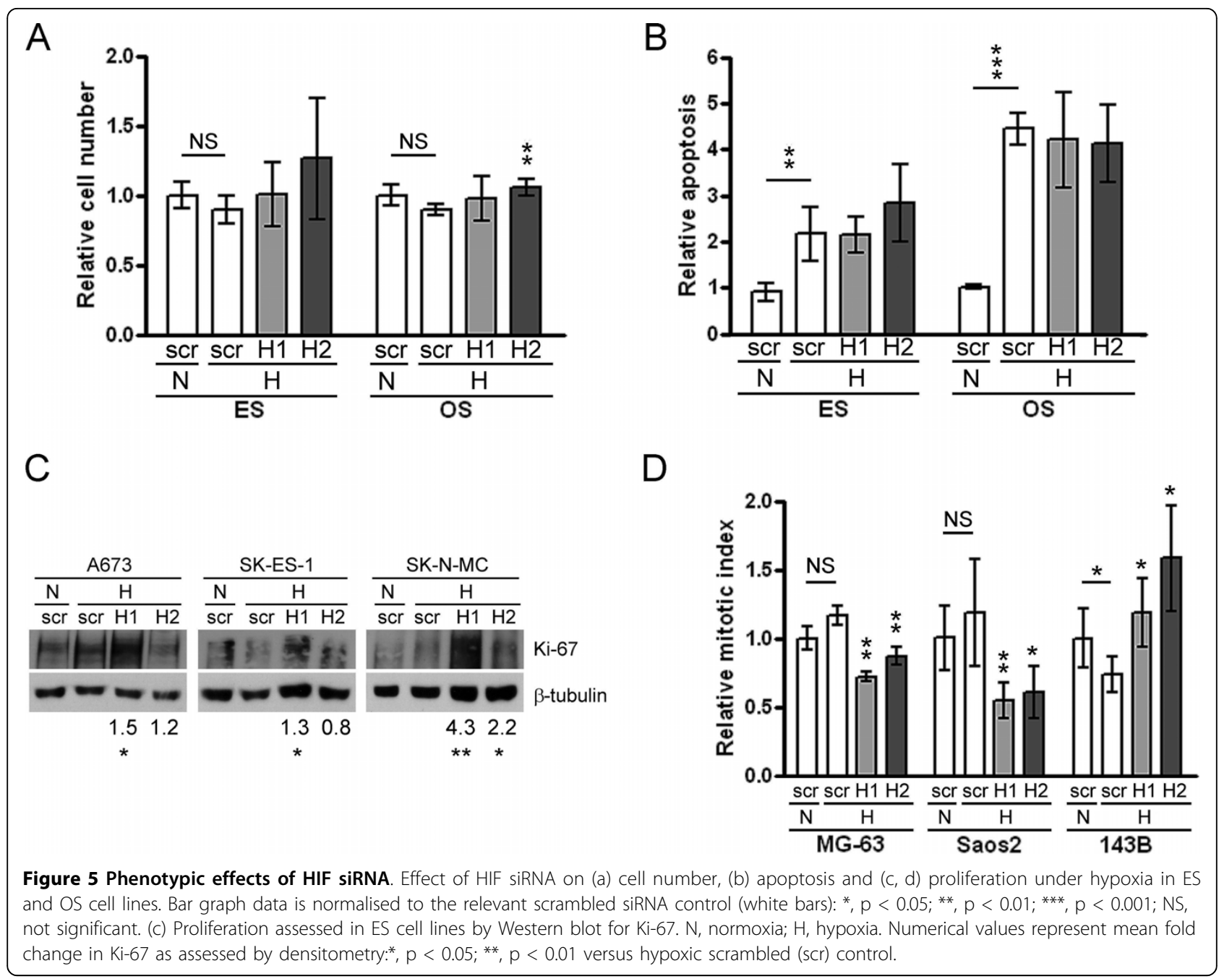

expression of VEGF, Glut-1 and PGK (the luciferase assay HRE) being mediated solely by HIF-1 $\alpha$. Also in accordance with previous results [32,34], inducible HIF$2 \alpha$ stimulated expression of HIF-2-specific genes, e.g. TGF $\alpha$, suggesting that HIF- $2 \alpha$ is functional in ES cells but that its effects are normally masked by HIF-1 $\alpha$ to regulate the majority of HIF-dependent genes. In contrast, gene expression in OS cells was regulated by both HIF isoforms. Indeed, the observed shift towards relative transcriptional domination of HIF- $2 \alpha$ places OS cells in a small group, including 786-0 renal cancer cells and the MDA-MB-435 melanoma cell line [27,28], displaying preferential utilisation of HIF- $2 \alpha$.

Hypoglycaemic induction of HIF- $2 \alpha$ is the second transcriptional feature distinguishing ES and OS cell lines. Reports of HIF pathway induction under low glucose conditions suggest a specific role for HIF- $2 \alpha$, for example in neuroblastoma cell lines [35]. Similarly, embryonic stem cells and pancreatic cancer cells under hypoglycaemia induced HIF target gene expression in a manner dependent on the HIF $\alpha$ dimerisation partner ARNT [36], but independent of HIF-1 $\alpha$ [37]. Our results in ES cell lines also suggest a dominant role for HIF- $2 \alpha$ in regulation of the HIF response to hypoglycaemia. Hypoxic stabilisation of HIF- $1 \alpha$ is dependent on the presence of glucose [38], which regulates translation via effects on the mTOR/Akt pathway $[39,40]$. The lack of a HIF transcriptional response to low glucose in OS cells may represent a differential sensitivity to glucose deprivation. This could be a consequence of the high levels of $\mathrm{PAS}^{+}$glycogen present in ES cells [41] that might provide sufficient intracellular available glucose for translation of HIF under hypoglycaemic conditions.

Phenotypic effects of prolonged exposure to hypoxia and low glucose were similar in both cell types. Hypoxia did not affect cell number, despite evidence of increased apoptosis. Hypoglycaemia produced a $\geq 45 \%$ reduction in cell number, predominantly due to reduced cellular proliferation. The only previous reports on apoptosis in ES cell lines described A673 as resistant [23] and 


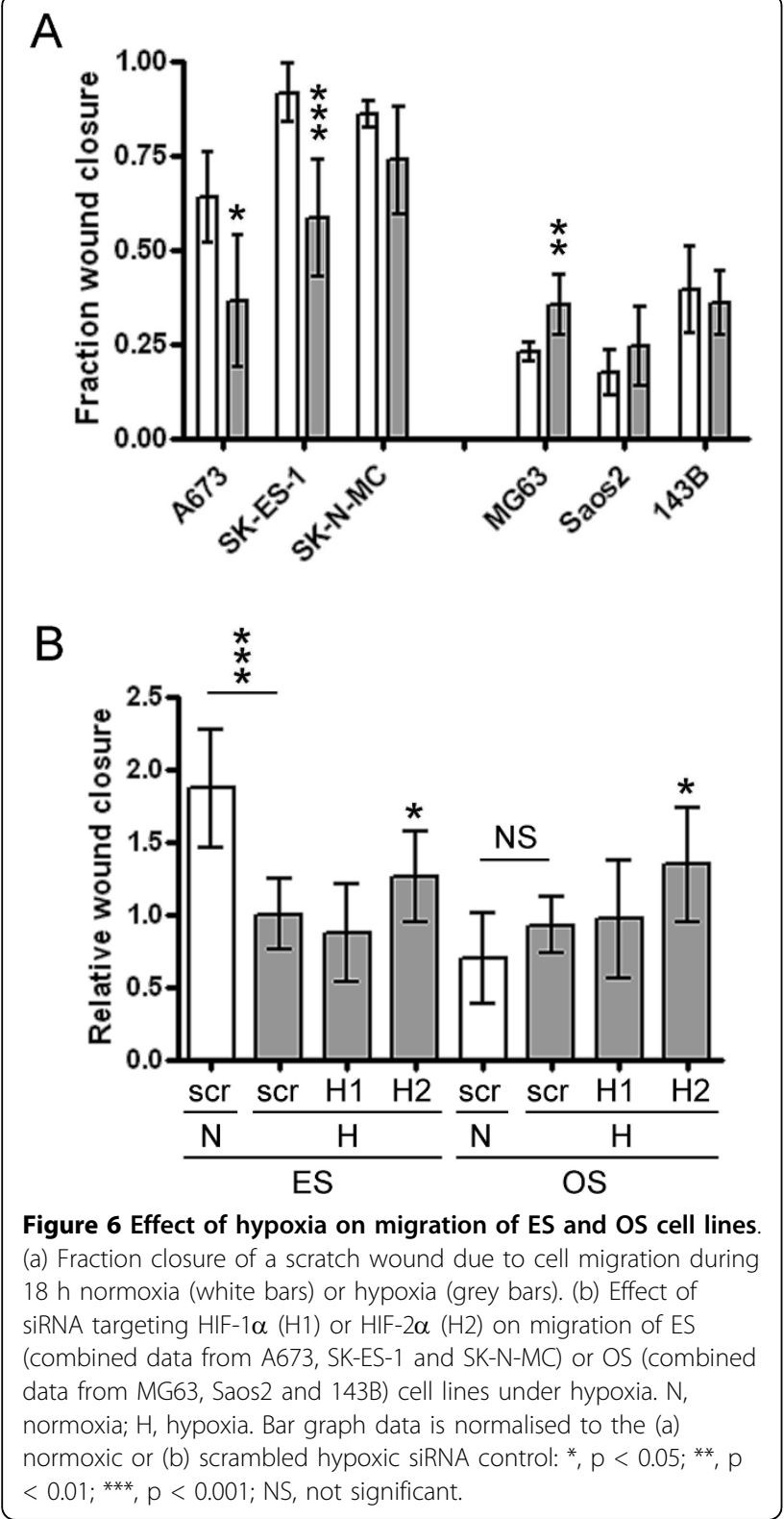

SK-N-MC as sensitive [42] to hypoxia-induced apoptosis. Our results for A673 and SK-N-MC show a 2 to 3fold increase in apoptosis after $72 \mathrm{~h}$ at $0.1 \% \mathrm{O}_{2}$, longer exposure to more severe hypoxia potentially explaining the increased apoptosis in A673. Hypoxia-induced apoptosis of OS cells has not previously been reported, but was generally 2 -fold greater than that in ES cell lines. There is considerably less data regarding hypoglycaemia-induced apoptosis [43], suggesting that this is potentially a cell type-specific response which was largely absent from either ES or OS cell lines.

It is intriguing that both ES and OS cells were sensitive to hypoxia-induced apoptosis but that HIF siRNA had no effect on the apoptotic phenotype. In the majority of cells, hypoxia-induced apoptosis is mediated by HIF- $1 \alpha[23,44,45]$. However there is an increasing literature suggesting that, in some cell types, apoptosis induced by severe hypoxia is HIF- $1 \alpha$-independent $[46,47]$. However, in ES in vivo expression of HIF-1 $\alpha$ and cleaved caspase 3 localised to areas adjacent to necrotic, and presumably hypoxic, tissue and HIF-1 $\alpha$ has been correlated with the percentage of dead cells in OS tumours [6]., This suggests some in vivo relationship between HIF and apoptosis which we have been unable to dissect in the in vitro situation.

The first phenotypic difference between ES and OS cell lines was the effect of HIF siRNA on hypoxic proliferation. Although overall proliferation rates were similar in normoxia and hypoxia in both cell types, HIF- $1 \alpha$ siRNA enhanced proliferation 2 to 3 -fold in ES cells whereas in $2 / 3$ OS cell lines both HIF- $1 \alpha$ and HIF- $2 \alpha$ siRNA inhibited hypoxic proliferation. It is not uncommon for HIF- $1 \alpha$ and HIF- $2 \alpha$ to exert opposing phenotypic effects in different cell lines. For example, HIF- $2 \alpha$ is necessary to maintain tumour growth in RCC4 renal carcinoma cells [48], potentially via regulation of the cell cycle regulatory proteins TGF $\alpha$ and cyclin D1. It may also specifically promote proliferation by enhancing activity of the c-Myc oncoprotein [49], in contrast to inhibition of cell cycle progression by HIF- $1 \alpha$ counteracting c-Myc transcriptional activity [50]. Conversely, in SW480 colon cancer cells, HIF-1 $\alpha$ siRNA inhibits proliferation whereas HIF- $2 \alpha$ siRNA increases anchorage independent growth [51].

The second phenotypic difference between the two cell types encompassed hypoxic migration, which was inhibited in ES cells and maintained or increased in OS cell lines. In both cell types, however, HIF- $2 \alpha$ siRNA stimulated hypoxic migration, suggesting an effect of HIF$2 \alpha$ to inhibit cell migration under hypoxia. There are many reports demonstrating migration to be dependent on either HIF- $1 \alpha$ and/or HIF- $2 \alpha$ in different cell types $[27,51,52]$, again demonstrating the ability of HIF- $1 \alpha$ and HIF- $2 \alpha$ to exert distinct phenotypic effects in different cell lines.

This data implicates hypoxia as the primary microenvironmental stimulus inducing expression of HIF and downstream genes in both ES and OS cells in culture. However, phenotypic results in both cell types suggest that hypoxia does not significantly increase either cell number or migration and, in addition, enhances tumour cell apoptosis. This does not correlate with clinical reports that hypoxia [9,16-18] and/or HIF-1 $\alpha$ [6-8] are predictive of poor outcome in these tumours. This may be due to antagonistic effects of genes downstream of HIF, which cancel each other out when manipulating the whole pathway in vitro. For example, VEGF blockade decelerates the growth of experimental 
osteosarcoma [53] and Ewing's sarcoma [54], demonstrating the viablility of specific targeting of HIF downstream genes. Despite being currently unable to dissect specific mechanisms by which HIF promotes ES and OS progression in vivo, we have identified features of the HIF pathway which distinguish the two cell types. This provides a solid platform from which to advance our understanding of the role of hypoxia and HIF in the biology of primary bone sarcomas.

\section{Conclusions}

To our knowledge, this study represents the first comprehensive report of effects of hypoxia and hypoglycaemia on HIF expression, transcriptional activation and phenotype of ES and OS cells. The two cell types differed with respect to their HIF isoform-specific transcriptional response to hypoxia and hypoglycaemia. Phenotypically, ES and OS cells demonstrated opposing migratory responses to hypoxia and opposing HIF-specific effects on hypoxic proliferation. Although the specific mechanism(s) whereby HIF promotes ES and OS progression in vivo remains to be identified, this data provides a comprehensive characterisation from which to advance our understanding of HIF function in the pathobiology of primary bone sarcomas.

\section{Acknowledgements}

This study was funded by EuroBoNeT, a European Commission-granted European Network of Excellence for studying the pathology and genetics of bone tumours (LSHCCT-2006-018 814). HJK and NAA are additionally supported by the Bone Cancer Research Trust (BCRT/06/08) and acknowledge support from the Oxford NIHR BRU. UD is also supported by Deutsche Krebshilfe: 50-2551 Jü3 und 50-2551-Jü4, the Federal Ministry of Education and Research Germany, BMBF (TranSaRNet) and Deutsches Zentrum für Luft und Raumfahrt e.V.

\section{Author details}

${ }^{1}$ Botnar Research Centre, University of Oxford, Nuffield Orthopaedic Centre, Oxford, OX3 7LD, UK. ${ }^{2}$ Univ Dusseldorf, Institute of Pathology, University Medical Centre Duesseldorf, D-40225 Dusseldorf, Germany. ${ }^{3}$ Paediatric Haematology \& Oncology, University Hospital Muenster, 48149 Muenster, Germany. ${ }^{4}$ Department of Pathology, Nuffield Department of Orthopaedic Surgery, University of Oxford, Nuffield Orthopaedic Centre, Oxford, OX3 7LD, UK

\section{Authors' contributions}

HJK designed the study, performed the experimental work and wrote the manuscript. KLS constructed the ES tissue microarray. UD collected samples and patient information for the tissue microarray. NAA conceived the study, contributed to the study design and writing of the manuscript and provided additional ES tissue sections. All authors read and approved the final manuscript.

\section{Competing interests}

The authors declare that they have no competing interests.

Received: 6 May 2010 Accepted: 16 July 2010 Published: 16 July 2010

\section{References}

1. Vaupel P, Mayer A: Hypoxia in cancer: significance and impact on clinical outcome. Cancer Metastasis Rev 2007, 26:225-239.
2. Epstein AC, Gleadle JM, McNeill LA, Hewitson KS, O'Rourke J, Mole DR, Mukherji M, Metzen E, Wilson MI, Dhanda A, Tian YM, Masson N, Hamilton DL, Jaakkola P, Barstead R, Hodgkin J, Maxwell PH, Pugh CW, Schofield CJ, Ratcliffe PJ: C. elegans EGL-9 and mammalian homologs define a family of dioxygenases that regulate HIF by prolyl hydroxylation. Cell 2001, 107:43-54

3. Bruick RK, McKnight SL: A conserved family of prolyl-4-hydroxylases that modify HIF. Science 2001, 294:1337-1340.

4. Harris AL: Hypoxia-a key regulatory factor in tumour growth. Nat Rev Cancer 2002, 2:38-47

5. Maynard MA, Ohh M: The role of hypoxia-inducible factors in cancer. Cell Mol Life Sci 2007, 64:2170-2180.

6. Yang QC, Zeng BF, Dong Y, Shi ZM, Jiang ZM, Huang J: Overexpression of Hypoxia-Inducible Factor-1\{alpha\} in Human Osteosarcoma: Correlation with Clinicopathological Parameters and Survival Outcome. Jap J Clin Oncol 2007, 37:127-134.

7. Mizobuchi H, Garcia-Castellano JM, Philip S, Healey JH, Gorlick R: Hypoxia markers in human osteosarcoma: An exploratory study. Clin Orthopaed Rel Res 2008, 466:2052-2059.

8. Chen WL, Feng HJ, Li HG: Expression and significance of hypoxemiainducible factor-1 alpha in osteosarcoma of the jaws. Oral Surg Oral Med Oral Pathol Oral Radiol Endodontol 2008, 106:254-257.

9. van der Schaft DW, Hillen F, Pauwels P, Kirschmann DA, Castermans K, Egbrink MG, Tran MG, Sciot R, Hauben E, Hogendoorn PC, Delattre O, Maxwell PH, Hendrix MJ, Griffioen AW: Tumor cell plasticity in Ewing sarcoma an alternative circulatory system stimulated by hypoxia. Cancer Res 2005, 65:11520-11528.

10. Kubo T, Sugita T, Shimose $S$, Matsuo T, Arihiro K, Ochi M: Expression of hypoxia-inducible factor- 1 alpha and its relationship to tumour angiogenesis and cell proliferation in cartilage tumours. J Bone Joint Surg-Br Vol 2008, 90B:364-370.

11. Knowles HJ, Athanasou NA: Hypoxia-inducible factor is expressed in giant cell tumour of bone and mediates paracrine effects of hypoxia on monocyte-osteoclast differentiation via induction of VEGF. J Pathol 2008, 215:56-66

12. Holzer G, Obermair A, Koschat M, Preyer O, Kotz R, Trieb K: Concentration of vascular endothelial growth factor (VEGF) in the serum of patients with malignant bone tumors. Med Pediat Oncol 2001, 36:601-604.

13. Kreuter M, Paulussen M, Boeckeler J, Gerss J, Buerger H, Liebscher C, Kessler $T$, Jurgens $H$, Berdel WE, Mesters RM: Clinical significance of vascular endothelial growth factor - a expression in Ewing's sarcoma. Eur J Cancer 2006, 42:1904-1911.

14. Kaya M, Wada T, Akatsuka T, Kawaguchi S, Nagoya S, Shindoh M, Higashino F, Mezawa F, Okada F, Ishii S: Vascular endothelial growth factor expression in untreated osteosarcoma is predictive of pulmonary metastasis and poor prognosis. Clin Cancer Res 2000, 6:572-577.

15. Kaya M, Wada T, Kawaguchi S, Nagoya S, Yamashita T, Abe Y, Hiraga H, Isu K, Shindoh M, Higashino F, Okada F, Tada M, Yamawaki S, Ishii S: Increased pre-therapeutic serum vascular endothelial growth factor in patients with early clinical relapse of osteosarcoma. Brit J Cancer 2002, 86:864-869.

16. Dunst J, Ahrens S, Paulussen M, Burdach S, Jurgens H: Prognostic impact of tumor perfusion in MR-imaging studies in Ewing tumors. Strahlenther Onkol 2001, 177:153-159.

17. Jenkin RD, Al-Fawaz I, Al-Shabanah M, Allam A, Ayas M, Khafaga Y, Memon M, Rifai S, Schultz H, Younge D: Localised Ewing Sarcoma/PNET of bone - Prognostic factors and international data comparison. Med Pediat Oncol 2002, 39:586-593.

18. Kavalar R, Marinsek ZP, Jereb B, Cagran B, Golouh R: Prognostic value of CD99, CD117, p53 and bcl-2 in Ewing sarcoma family tumours. Eur J Oncol 2007, 12:243-253.

19. Mayes PA, Campbell L, Ricci MS, Plastaras JP, Dicker DT, El-Deiry WS Modulation of TRAIL-induced tumor cell apoptosis in a hypoxic environment. Cancer Biol Ther 2005, 4:1068-1074.

20. Kim HH, Lee SE, Chung WJ, Choi Y, Kwack K, Kim SW, Kim MS, Park H, Lee $\mathrm{ZH}$ : Stabilization of hypoxia-inducible factor-1 alpha is involved in the hypoxic stimuli-induced expression of vascular endothelial growth factor in osteoblastic cells. Cytokine 2002, 17:14-27.

21. Doege K, Heine S, Jensen I, Jelkmann W, Metzen E: Inhibition of mitochondrial respiration elevates oxygen concentration but leaves 
regulation of hypoxia-inducible factor (HIF) intact. Blood 2005 106:2311-2317.

22. Akeno N, Czyzyk-Krzeska MF, Gross TS, Clemens TL: Hypoxia induces vascular endothelial growth factor gene transcription in human osteoblast-like cells through the hypoxia-inducible factor-2alpha. Endocrinol 2001, 142:959-962.

23. Kilic M, Kasperczyk H, Fulda S, Debatin KM: Role of hypoxia inducible factor-1 alpha in modulation of apoptosis resistance. Oncogene 2007, 26:2027-2038

24. Yeo EJ, Chun YS, Cho YS, Kim JH, Lee JC, Kim MS, Park JW: YGI: A potential anticancer drug targeting hypoxia-inducible factor 1. J Natl Cancer Inst 2003, 95:516-525.

25. Guan H, Jia SF, Zhou Z, Stewart J, Kleinerman ES: Herceptin downregulates HER-2/neu and vascular endothelial growth factor expression and enhances taxol-induced cytotoxicity of human Ewing's sarcoma cells in vitro and in vivo. Clin Cancer Res 2005, 11:2008-2017.

26. Ottaviano L, Schaefer KL, Gajewski M, Huckenbeck W, Baldus S, Rogel U, Mackintosh C, de Alava E, Myklebost O, Kresse SH, Meza-Zepeda LA Serra M, Cleton-Jansen AM, Hogendoorn PC, Buerger H, Aigner T, Gabbert HE, Poremba C: Molecular characterization of commonly used cell lines for bone tumor research: a trans-European EuroBoNet effort. Genes Chromosomes Cancer 49:40-51.

27. Sowter HM, Raval RR, Moore JW, Ratcliffe PJ, Harris AL: Predominant role of hypoxia-inducible transcription factor (Hif)-1alpha versus Hif-2alpha in regulation of the transcriptional response to hypoxia. Cancer Res 2003, 63:6130-6134.

28. Raval RR, Lau KW, Tran MGB, Sowter HM, Mandriota SJ, Li JL, Pugh CW, Maxwell PH, Harris AL, Ratcliffe PJ: Contrasting properties of hypoxiainducible factor 1 (HIF-1) and HIF-2 in von Hippel-Lindau-associated renal cell carcinoma. Mol Cell Biol 2005, 25:5675-5686.

29. Covello KL, Simon MC, Keith B: Targeted replacement of hypoxiainducible factor-1alpha by a hypoxia-inducible factor-2alpha knock-in allele promotes tumor growth. Cancer Res 2005, 65:2277-2286.

30. Qing GL, Simon MC: Hypoxia inducible factor-2 alpha: a critical mediator of aggressive tumor phenotypes. Curr Opin Genet Dev 2009, 19:60-66.

31. Warnecke C, Weidemann A, Volke M, Schietke R, Wu XQ, Knaup KX, Hackenbeck T, Bernhardt W, Willam C, Eckardt KU, Wiesener MS: The specific contribution of hypoxia-inducible factor-2 alpha to hypoxic gene expression in vitro is limited and modulated by cell type-specific and exogenous factors. Exp Cell Res 2008, 314:2016-2027.

32. Warnecke C, Zaborowska Z, Kurreck J, Erdmann VA, Frei U, Wiesener M, Eckardt KU: Differentiating the functional role of hypoxia-inducible factor (HIF)-1 alpha and HIF-2 alpha (EPAS-1) by the use of RNA interference: erythropoietin is a HIF-2 alpha target gene in Hep3B and Kelly cells. Faseb J 2004, 18:1462.

33. Mole DR, Blancher C, Copley RR, Pollard PJ, Gleadle JM, Ragoussis J, Ratcliffe PJ: Genome-wide Association of Hypoxia-inducible Factor (HIF)-1 alpha and HIF-2 alpha DNA Binding with Expression Profiling of Hypoxia-inducible Transcripts. J Biol Chem 2009, 284:16767-16775.

34. Batra S, Perelman N, Luck LR, Shimada H, Malik P: Pediatric tumor cells express erythropoietin and a functional erythropoietin receptor that promotes angiogenesis and tumor cell survival. Lab Invest 2003, 83:1477-1487.

35. Nilsson H, Jogi A, Beckman S, Harris AL, Poellinger L, Pahlman S: HIF-2 alpha expression in human fetal paraganglia and neuroblastoma: relation to sympathetic differentiation glucose deficiency and hypoxia. Exp Cell Res 2005, 303:447-456.

36. Maltepe E, Schmidt JV, Baunoch D, Bradfield CA, Simon MC: Abnormal angiogenesis and responses to glucose and oxygen deprivation in mice lacking the protein ARNT. Nature 1997, 386:403-407.

37. Natsuizaka M, Ozasa M, Darmanin S, Miyamoto M, Kondo S, Kamada S Shindoh M, Higashino F, Suhara W, Koide H, Aita K, Nakagawa K, Kondo T, Asaka M, Okada F, Kobayashi M: Synergistic up-regulation of Hexokinase2 , glucose transporters and angiogenic factors in pancreatic cancer cells by glucose deprivation and hypoxia. Exp Cell Res 2007, 313:3337-3348.

38. Vordermark D, Kraft P, Katzer A, Bolling T, Willner J, Flentje M: Glucose requirement for hypoxic accumulation of hypoxia-inducible factor-1 alpha (HIF-1 alpha). Cancer Lett 2005, 230:122-133.

39. Kwon SJ, Lee YJ: Effect of low glutamine/glucose on hypoxia-induced elevation of hypoxia-inducible factor-1 alpha in human pancreatic cancer MiaPaCa-2 and human prostatic cancer DU-145 cells. Clin Cancer Res 2005, 11:4694-4700.

40. Harada H, Itasaka S, Kizaka-Kondoh S, Shibuya K, Morinibu A, Shinomiya K, Hiraoka M: The Akt/mTOR Pathway Assures the Synthesis of HIF-1 alpha Protein in a Glucose- and Reoxygenation-dependent Manner in Irradiated Tumors. J Biol Chem 2009, 284:5332-5342.

41. Kissane JM, Askin FB, Foulkes M, Stratton LB, Shirley SF: Ewing's sarcoma of bone: clinicopathologic aspects of 303 cases from the Intergroup Ewing's Sarcoma Study. Hum Pathol 1983, 14:773-779.

42. Araya R, Uehara T, Nomura Y: Hypoxia induces apoptosis in human neuroblastoma SK-N-MC cells by caspase activation accompanying cytochrome c release from mitochondria. FEBS letters 1998, 439:168-172.

43. Brusselmans $K$, Bono F, Maxwell P, Dor Y, Dewerchin M, Collen D, Herbert JM, Carmeliet P: Hypoxia-inducible factor-2 alpha (HIF-2 alpha) is involved in the apoptotic response to hypoglycemia but not to hypoxia. J Biol Chem 2001, 276:39192-39196.

44. Carmeliet P, Dor Y, Herbert JM, Fukumura D, Brusselmans K, Dewerchin M, Neeman M, Bono F, Abramovitch R, Maxwell P, Koch CJ, Ratcliffe P, Moons L, Jain RK, Collen D, Keshet E: Role of HIF-1 alpha or in hypoxiamediated apoptosis cell proliferation and tumour angiogenesis. Nature 1998, 394:485-490

45. Halterman MW, Miller CC, Federoff HJ: Hypoxia-inducible factor-1 alpha mediates hypoxia-induced delayed neuronal death that involves p53. $J$ Neurosci 1999, 19:6818-6824.

46. Papandreou I, Krishna C, Kaper F, Cai DL, Giaccia AJ, Denko NC: Anoxia is necessary for tumor cell toxicity caused by a low-oxygen environment. Cancer Res 2005, 65:3171-3178.

47. Brunelle JK, Shroff EH, Perlman H, Strasser A, Moraes CT, Flavell RA, Danial NN, Keith B, Thompson CB, Chandel NS: Loss of MCl-1 protein and inhibition of electron transport chain together induce anoxic cell death. Mol Cell Biol 2007, 27:1222-1235.

48. Kondo K, Kim WY, Lechpammer M, Kaelin WG: Inhibition of HIF2 alpha is sufficient to suppress pVHL-defective tumor growth. Plos Biol 2003, 1:439-444.

49. Gordan JD, Bertout JA, Hu CJ, Diehl JA, Simon MC: HIF-2alpha promotes hypoxic cell proliferation by enhancing c-myc transcriptional activity. Cancer Cell 2007, 11:335-347.

50. Koshiji M, Kageyama Y, Pete EA, Horikawa I, Barrett JC, Huang LE: HIF-1 alpha induces cell cycle arrest by functionally counteracting Myc. Embo $J$ 2004, 23:1949-1956.

51. Imamura T, Kikuchi H, Herraiz MT, Park DY, Mizukami Y, Mino-Kenduson M, Lynch MP, Rueda BR, Benita Y, Xavier RJ, Chung DC: HIF-1 alpha and HIF-2 alpha have divergent roles in colon cancer. Int I Cancer 2009, 124:763-771.

52. Ben-Shoshan J, Schwartz S, Luboshits G, Maysel-Auslender S, Barzelay A, Polak-Charcon S, Tzahor E, Barshack I, Barak A, Levkovitch-Verbin H, Keren G, George J: Constitutive Expression of HIF-1 alpha and HIF-2 alpha in Bone Marrow Stromal Cells Differentially Promotes Their Proangiogenic Properties. Stem Cells 2008, 26:2634-2643.

53. Yin DZ, Jia TH, Gong WM, Yu HY, Wooley PH, Mott MP, Yang SY: VEGF blockade decelerates the growth of a murine experimental osteosarcoma. Int J Oncol 2008, 33:253-259.

54. Guan H, Zhou ZC, Wang H, Jia SF, Liu WB, Kleinerman ES: A small interfering RNA targeting vascular endothelial growth factor inhibits Ewing's sarcoma growth in a xenograft mouse model. Clin Cancer Res $2005,11: 2662-2669$.

\section{Pre-publication history}

The pre-publication history for this paper can be accessed here: http://www.biomedcentral.com/1471-2407/10/372/prepub

doi:10.1186/1471-2407-10-372

Cite this article as: Knowles et al: Hypoxia and hypoglycaemia in Ewing's sarcoma and osteosarcoma: regulation and phenotypic effects of Hypoxia-Inducible Factor. BMC Cancer 2010 10:372. 